\title{
WISATA ZIARAH SEBAGAI IDENTITAS SOSIAL: STUDI ANTROPOLOGI BUDAYA DI MAKAM SULTAN MALIKUSSALEH KECAMATAN SAMUDERA, KABUPATEN ACEH UTARA
}

\author{
Muliadi ${ }^{1}$, Teuku Kemal Fasya ${ }^{1}$, Iromi Ilham ${ }^{1}$ \\ 1 Program Studi Antropologi, Fakultas Ilmu Sosial dan Ilmu Politik, Universitas \\ Malikussaleh.
}

Korespondensi: muliady023@gmail.com

\begin{abstract}
Abtrak: Ziarah awalnya merupakan kegiatan ritual keagamaan, kemudian berkembang menjadi wisata ziarah (pilgrimage tourism). Wisata ziarah adalah perjalanan wisata yang tujuaanya berkaitan dengan agama, sejarah, adat istiadat dan kepercayaan dari peserta tur atau kelompok dari masyarakat. Praktik ziarah memunculkan perilaku yang bervariasi diantara satu daerah dengan yang lainnya. Penelitian ini mengkaji tentang "Wisata Ziarah Sebagai Identitas Sosial (Studi Antropologi Budaya di Makam Sultan Malikussaleh Kecamatan Samudera, Kabupaten Aceh Utara)". Penelitian ini menggunakan metode sosial kualitatif dengan pendekatan kualitatif. Pengumpulan data penelitian dilakukan dengan teknik observasi, wawancara, studi dokumen, dan studi literatur. Penelitian ini bertujuan untuk mengetahui motif serta perilaku peziarah yang bisa diidentifikasi sebagai identitas sosial masyarakat. Hasil penelitian ini menunjukkan bahwa Ada beberapa motif peziarah mengunjungi makam Sultan Malikussaleh, diantaranya; (1) karena tradisi agama, (2) sebagai wasilah atau perantara berdoa, dan (3) cok beurkat (mengambil keberkahan). Kemudian berdasarkan tujuan pelaksanaan ziarah, ada beberapa perilaku yang sering terjadi di Makam Sultan Malikussaleh, diantaranya berdoa, peuphon kitab, bernazar, dan belajar sejarah. Perilaku tersebut cenderung menampilkan karakter identitas masyarakat Aceh dalam berziarah.
\end{abstract}

Kata Kunci: Ziarah, Sultan Malikussaleh, Identitas Sosial, Antropologi Budaya 


\section{A. Pendahuluan}

Ziarah merupakan fenomena yang selalu ada pada setiap umat manusia sepanjang sejarahnya. Ziarah termasuk bagian dari ritual keagamaan serta telah menjadi suatu kebudayaan dalam masyarakat. Dengan demikian tindakan ziarah disebut sebagai suatu tindakan kebudayaan yang mempunyai makna dan fungsi tersendiri bagi para pelaku (Syahdan, 2017). Awalnya ziarah hanya dilakukan untuk mengunjungi sanak saudara, keluarga, kerabat dan lain-lain yang sudah lebih dulu meninggalkan dunia. Hingga pada saat ini berkembang menjadi ziarah pada makam wali, kyai, atau orang yang dianggap hebat dalam masyarakat (Biroli, 2015). Artinya, perkembangan zaman menjadikan ziarah sebagai suatu fenomena yang lazim yang dijumpai di dalam suatu masyarakat. Akibatnya, praktik ziarah kemudian mengalami perkembangan. Ziarah bukan saja soal ibadah dan perilaku agama. Namun aspek sosial dan politik juga tidak kurang penting (Biroli, 2015), sehingga berbagai macam tindakan terjadi dengan beragam bentuk perilaku ziarah.

Tradisi ziarah secara turun-temurun dilestarikan oleh para pendukungnya dengan berbagai motivasi dan tujuan yang tidak lepas dari pandangan hidup masyarakat pada umumnya. Praktik ziarah saat ini memunculkan perilaku yang bervariasi diantara satu daerah dengan yang lainnya. Keadaan ini dikarenakan praktik ziarah dilakukan dengan berbagai motivasi dan tujuan yang tidak lepas dari pandangan hidup dan budaya masing-masing masyarakat.

Secara umum ziarah termasuk bagian dari ritual keagamaan. Dan ritual erat kaitannya dengan identitas, karena melalui ritual maka kelompok-kelompok pelaksana ritual dapat mengkomunikasikan dan merefleksikan eksistentensinya melalui berbagai simbol, yang sarat makna dan sekaligus menjadi penanda identitasnya (Rumuhuru, 2012). Karena itu, perilaku atau karakter setiap individu dilatarbelakangi oleh karakteristik suatu identitas.

Dalam penelitian ini identitas dimaksudkan yaitu identitas kelompok atau identitas sosial (social identity). Setiap masyarakat memiliki identitas dan karakteristik masing-masing. Perbedaan karakteristik identitas dapat dilihat dari sumber-sumber identitas yang penting mencakup nasionalitas, etnisitas, 
seksualitas, gender, dan kelas. Meskipun individulah yang memiliki identitas, konsep ini berkaitan juga dengan kelompok sosial tempat individu menjadi bagiannya dan menjadi dasar rujukan identifikasinya (Rahmaniah, 2012) disebut identitas sosial (social identity). Secara antropologis, konsep identitas sosial mengandung makna yang sama dengan konsep identitas etnis, yaitu merujuk pada keseluruhan aspek masalah-masalah etnis, seperti kepercayaan, pengetahuan, budaya, agama, bahasa, dan adat istiadat yang diwarisi (Rahmaniah, 2012).

Berdasarkan latar belakang masalah yang telah diuraikan di atas maka rumusan permasalahan yang diteliti adalah: (1) Apa yang menjadi motivasi peziarah mengunjungi makam Sultan Malikussaleh?; (2) Bagaimana perilaku ziarah yang terjadi di Makam Sultan Malikussaleh yang bisa diidentifikasi sebagai identitas sosial KeAcehan?. Karena itu, maka penelitian ini memfokuskan pada tujuan untuk mencari tahu motivasi peziarah dan menjelaskan perilaku peziarah di makam Sultan Malikussaleh sebagai identitas sosial keAcehan.

\section{B. Metode Penelitian}

Penelitian ini dilakukan di area makam Sultan Malikussaleh yang berada Gampong Beuringen, Kecamatan Samudera Kabupaten Aceh Utara Provinsi Aceh. Makam Sultan Malikussaleh adalah salah satu makam raja di Aceh yang sering dikunjungi dan dikenal oleh masyarakat luas. Selain itu makam Sultan Malikussaleh merupakan salah satu situs cagar budaya yang bisa menumbuhkan rasa kepedulian masyarakat terhadap sejarah Aceh.

Penelitian ini merupakan penelitian sosial yang menggunakan metode kualitatif dengan fokus kajian Antropologi Budaya. Data yang diperoleh dalam penelitian ini adalah data kualitatif sehingga metode analisis yang digunakan merupakan metode analisis data kualitatif. Penelitian ini menggunakan penelitian kualitatif dengan maksud untuk memperoleh gambaran yang mendalam dengan menghasilkan data deskriptif tentang masalah yang diamati (Moleong, 2014).

\section{Teknik Pengumpulan Data}

Penelitian ini merupakan suatu penelitian kualitatif dengan jenis penelitian lapangan (Field Reasecrh). Secara umum dalam penelitian kualitatif ini, jenis data dapat dibagi menjadi dua jenis, antara lain; (1) Data primer, yaitu data yang 
diperoleh dari hasil observasi partisipatif (participant observation) dan hasil wawancara (interview) dengan informan di lapangan. (2) Data sekunder, yaitu data yang diperoleh dari dokumen literatur yang memperkaya dari hasil temuan data primer. Adapun data sekunder yang digunakan dalam penelitian ini dari berbagai buku, jurnal, dan informasi online.

Informan yang menjadi sumber data terkait dengan tema penelitian ini ada dua jenis, antara lain; (1) informan penghubung, yaitu sebagai penghubung kepada informan kunci. Informan penghubung dalam penelitian ini adalah Kepala Desa (Pak Geuchik). (2) Informan kunci, yaitu mereka yang mengetahui dan memiliki informasi atau data utama yang diperlukan dalam penelitian. Informan kunci disini ialah; Teungku Khadam makam Sultan Malikussaleh dan anggota masyarakat atau pengunjung yang sedang melakukan ziarah di Makam Sultan Malikussaleh.

\section{Pembahasan}

\section{Makam Sultan Malikussaleh}

Sultan Malikussaleh tidak diketahui pasti kapan dan dimana ia dilahirkan, akan tetapi Sultan Malikussaleh wafat pada 17 Ramadhan tahun 696 H (1297 M) dan dimakamkan di Gampong Beuringen, Kecamatan Samudera Kabupaten Aceh Utara. Mengenai penyebab mangkatnya Sultan Malikussaleh, dikisahkan bahwasanya ia meninggal disebabkan oleh gejala sakit yang dialaminya.

Keberadaan komplek makam Sultan Malikussaleh di dusun Teungku Syarif, Gampong Beuringen, Kecamatan Samudera Kabupaten Aceh Utara. Lokasi ini diyakini sebagai lokasi istana Kerajaan Samudera. Jalur utama menuju kawasan komplek makam yaitu ruas jalan lintas gampong dari Keude Geudong, sebagai arah kedatangan pengunjung makam Sultan Malikussaleh, sekaligus sebagai batas wilayah Gampong Beuringen dengan Gampong Krueng Matee.

Pemanfaatan dan pengelolaan situs cagar budaya makam Sultan Malikussaleh selama ini hanya dilakukan oleh sebagian tokoh warga masyarakat setempat. Dalam hal ini pengelolaan makam tersebut di bawah pimpinan Teungku Imuem Syik Gampong. ${ }^{1}$

${ }^{1}$ Teungku Imuem Syik Gampong merupakan suatu istilah yang digunakan oleh orang Aceh dalam konsep susunan struktur pemerintahan desa yang membidangi bidang keagamaan. 
Makam Sultan Malikussaleh dipercaya oleh masyarakat sebagai makam keramat. Kepercayaan ini muncul berdasarkan pengalaman mereka melihat atau mendengar kejaiban-keajaiban yang terjadi di makam tersebut. Pada saat Tsunami melanda Aceh pada tahun 2004 silam, Gampong Beuringen menjadi salah satu kawasan yang terkena langsung dampaknya. Semua rumah warga dan bangunan lainnya rubuh dihantam Tsunami, akan tetapi makam Sultan Malikussaleh tetap utuh dan tak tersentuh oleh Tsunami. Bahkan sebagian warga selamat karena berlindung di perkarangan makam Sultan Malikussaleh.

\section{Motivasi Ziarah}

Pengembangan kedudukan makam Sultan Malikusaleh sebagai suatu objek wisata bukan hanya melihat dari segi sarana dan fasilitas yang dimiliki, namun juga melihat kondisi dan persepsi atau padangan masyarakat sebagai pengunjung dalam menyikapi kegiatan yang berlaku dalam kegiatan ziarah. Sehingga dari hal itu kemudian bisa menjadi pondasi motivasi pengunjung dalam berziarah di makam Sultan Malikussaleh.

Ada beberapa motif orang berziarah ke makam Sultan Malikussaleh, diantaranya ialah;

1. Karena agama atau kepercayaan, mereka menyakini dengan mengunjungi atau menziarahi kuburan dapat mengingatkan akan kematian dan akhirat.

2. Meyakini akan keramatnya kuburan atau makam Sultan Malikussaleh mendorong masyarakat untuk menjadikan Sultan Malikussaleh sebagai wasilah atau perantara meminta pertolongan dalam memohon keselamatan hidup dari mara bahaya yang akan dihadapi. Masyarakat percaya dengan melalui perantaranya ahli kuburan yaitu Sultan Malikussaleh maka doa dan permohonan mereka akan mudah dikabulkan.

3. Cok beurkat. ${ }^{2}$ Dengan adanya anggapan akan keramatnya makam Sultan Malikussaleh itu diharapkan dapat memberi berkah yang bisa mengalir

\footnotetext{
${ }^{2}$ Cok beurkat adalah suatu konsep yang biasa digunakan oleh masyarakat Aceh yang memiliki arti mengambil keberkahan. Makna dari konsep ini juga dipakai oleh masyarakat jawa, akan tetapi dengan konsep yang berbeda, yaitu "Ngalap Berkah". Secara etimologi kata berkah diambil dari bahasa Arab, yaitu 'baraka', yang berarti kenikmatan dan kebahagiaan. Kemudian secara
} 
manfaatnya bagi orang yang masih hidup. Beberapa peziarah memahami keberkahan yang akan diperoleh sebagai suatu kebaikan dan ketenangan dalam kehidupannya. Sebagian yang lainnya memahami berkah dengan maksud agar mendapatkan kesejahteraan dan kebahagiaan hidup. Ada pula yang memahami bahwa keberkahan tersebut sebagai suatu bentuk kepuasan dan kemudahan spiritual dalam hidup.

\section{Perilaku Ziarah}

Pengembangan situs makam Sultan Malikussaleh sebagai objek wisata ziarah tentunya mempengaruhi gaya dan perilaku masyarakat dalam melakukan kegiatan ziarah. Berdasarkan motiv dan tujuan pelaksanaan ziarah, ada beberapa perilaku yang sering terjadi di makam Sultan Malikussaleh, diantaranya akan dijelaskan sebagai berikut:

\section{a. Menitih Harap Melalui Tawashul}

Berdoa merupakan salah satu cara yang dilakukan masyarakat untuk mencapai berbagai macam keinginannya. Tentunya doa-doa yang dipanjatkan pun seiring dengan kebutuhan serta keinginan yang ingin dicapai.

Kegiatan doa yang dilakukan oleh peziarah, di antara yang satu dengan lainnya memiliki variasi cara dalam berdoa. Akan tetapi, secara garis besar ada dua macam cara cara berdoa yang dilakukan di makam Sultan Malikussaleh, yaitu, berdoa sendiri dan berdoa secara berjamaah (kelompok) dengan membaca tahlil.

Tahlil dilakukan dengan membaca serangkaian surat-surat dan ayat-ayat pilihan dari Al-Quran, serta kalimat-kalimat zikir pilihan seperti membaca la ilaha illallah, yang kemudian ditutup dengan doa. Tahlil dilakukan dengan niat bahwa pahalanya ditujukan untuk para arwah. Kegiatan tahlilan dilakukan dengan dipimpin oleh satu orang dan yang lainnya mengikutinya. Kegiatan ini biasanya dilakukan oleh masyarakat yang tergabung dalam kelompok pengajian. Baik dari kalangan para teungku maupun para santri sendiri.

Berbeda halnya dengan berdoa secara berjamaah, berdoa sendiri dilakukan dengan suara pelan, dan bacaan-bacaan dibacakan berdasarkan dengan keinginan 
yang ingin diminta. Kemudian, sebagai penutup sekaligus pelengkap serangkaian ritual doa yang dilakukan di makam, para peziarah rah $u l e i^{3}$ di atas kubur Sultan Malikussaleh. Rah ulei dilakukan dengan harapan untuk mendapatkan keberkahan melalui bertawasul kepada arwah penghuni kubur. Kegiatan rah ulei terjadi berdasarkan keinginan sendiri peziarah dan bahkan anjuran dari teungku khadam. Perilaku ini muncul seiring anggapan bahwa dengan mencuci muka di tempat tersebut dapat memberi keberkahan ketenangan jiwa dan pikiran.

Kemudian kegiatan doa yang dilakukan di makam Sultan Malikussaleh sebagai bentuk tawashul. Seperti halnya yang dikutip dari media online, pada masa maraknya isu politik tahun 2016 lalu, pasangan Syamsuddin Jalil melakukan ziarah ke makam Sultan Malikussaleh. Dalam kunjungan tersebut mereka mendeklarasikan diri sebagai pasangan calon Bupati dan Wakil Bupati Aceh Utara periode 2017-2022. ${ }^{4}$ Deklarasi ini dilakukan di makam Sultan Malikussaleh untuk mengambil keberkatan dan ukhuwah dari doa-doa para sultan untuk meraih kesuksesan dalam Pilkada.

\section{b. Peuphon Kitab}

Peuphon kitab merupakan suatu ritual yang biasa dilakukan oleh sebagian masyarakat yang tergabung dalam suatu kelompok pengajian (santri). Kebiasaan ini sudah menjadi tradisi turun temurun. Ritual ini dilakukan dengan maksud untuk mendapatkan keberkahan. Pengunjung meyakini bahwa banyak keberkahan pada mereka yang sudah lama mengabdikan hidupnya dengan mengajarkan dan mensyiarkan ilmu agama kepada umat Nabi Muhammad SAW, salah satunya seperti Sultan Malikussaleh. Dengan demikian menjadikan Sultan Malikussaleh dan makamnya sesuatu yang diharapkan berkahnya sebagai perantara menuju keberkahan dari Allah.

\footnotetext{
${ }^{3}$ Rah ulei (bahasa Aceh) berarti cuci muka. Rah ulei adalah suatu ritual membasuh mukanya dengan air yang biasanya dicampur dengan beberapa jenis bunga dan jeruk purut. Akan tetapi kegiatan rah ule di makam Sultan Malikussaleh dengan air dicampur dengan batu dari pusara (kuburan) Sultan Malikussaleh.

4 Saifullah Nurdin, Ayah Panton Deklarasi di Makam Sultan Malikussaleh, di kutip dari https://m.rri.co.id/lhokseumawe/post/berita/297840/pilkada-serentak/ayah-panton-deklarasidi-makam-sultan-malikussaleh.html, 9 Agustus 2016.

${ }^{5}$ Peuphoen Kitab (bahasa Aceh) adalah ritual memulai pembacaan kitab baru yang akan dikaji dalam pengajian.
} 
Pengambilan berkah tersebut sangat berarti bagi mereka yang melakukannya. Agar dengan keberkatan tersebut menjadi washilah supaya diberi ketetapan hati, kemudahan dan kelancaran dalam proses pembelajaran atau pengkajian isi kitab. Karena pada umunya orang memiliki pandangan bahwa makam leluhur memiliki nilai-nilai khusus bagi orang yang bersangkutan.

Pelaksanaan ritual ini dilaksanakan dengan beberapa langkah, yaitu; (1) mengambil wudhu (bersuci), (2) ziarah ke makam Sultan Malikussaleh dengan posisi duduk mengelilingi kuburan dan menghadap ke arah kuburan. (3) peziarah melakukan doa bersama dalam bentuk tahlilan. (4) membaca kitab yang dipimpin dan dibaca oleh teungku pemimpin kelompok pengajian yang ditutup dengan doa dan selawat. (5) peusijuk6anggota pengajian. Prosesi ritual peusijuk dilakukan seperti pada umumnya.

Di akhir ziarahnya, masyarakat mengambil ie peunawa ${ }^{7}$ yang disediakan oleh teungku khadam bagi seluruh pengunjung apabila menginginkannya untuk dibawa pulang. Ie peunawa ini dipercaya oleh masyarakat bisa dijadikan sebagai penawar atau pun obat dari segala penyakit. Inti atau sumber dari ie peunawa tersebut adalah batu kerikil putih dari kuburan Sultan Malikussaleh yang dimasukkan ke dalam wadah. Batu ini di bawa oleh salah seorang yang dipercaya sebagai seorang wali yang berasal dari Wayla,8yaitu Abu Ibrahim. Hal inilah yang membuat munculnya penilaian lebih daripada para peziarah terhadap khasiat dari batu yang ada pada kubur tersebut.

\section{c. Bernazar' $^{9}$ (Meukaoi)}

Keberadaan makam Sultan Malikussaleh biasa dijadikan sebagai media untuk memperoleh berkah. Sehingga mendorong masyarakat untuk melepaskan hajatnya ketempat makam tersebut untuk memperoleh berkah.

${ }^{6}$ Peusijuk secara bahasa berarti pendingin atau membuat sesuatu menjadi dingin. Tujuan Peusijuk adalah untuk memberkati sesuatu termasuk di dalamnya mendoakan orang yang di peusijuk (dikutip dari https://www.kompasiana.com, Peusijuk, Tradisi warisan Leluhur Masyarakat Aceh.7 Juni 2013).

${ }^{7}$ Ie Peunawa berarti air penawar yang dipercayakan dan digunakan oleh masyarakat sebagai media untuk menyembuhkan penyakit.

${ }^{8}$ Wayla merupakan nama kecamatan suatu daerah yang terletak di Kabupaten Aceh Barat, Provinsi Aceh.

${ }^{9}$ Nazar secara bahasa adalah janji. Sedangkan menurut penegrtian syara' adalah menyanggupi melakukan ibadah yang bukan merupakan hal yang wajib bagi seseorang. Lihat $\mathrm{Nu}$ Online, Pengertian Nazar dan Ketentuannya dalam Islam, 22 September 2019. 
Bernazar ini berlangsung dengan melewati proses pola sebelum dan sesudah. Pada proses ini menunjukkan motiv dan tujuan masyarakat dalam melakukan nazarnya di makam Sultan Malikussaleh. Bernazar di makam Sultan Malikussaleh, untuk itu masyarakat melakukan beberapa tahapan. Pertama, berwudhu. Hal ini dilakukan sebagai anjuran dan adab dalam berziarah. Selain itu wudhu ini dilakukan untuk menyucikan diri agar bisa melanjutkan pada tahapan selanjutnya dalam proses bernazar.

Kedua, ziarah ke makam. Pada tahapan ini, masyarakat biasanya membawa sebotol air yang nantinya diberikan kepada teungku qadam. Namun hal ini juga tergantung pada tujuan nazar masyarakat. Ada juga masyarakat yang hanya membawa wadahnya saja untuk menampung air yang nantinya dijadikan sebagai penawar.

Ketiga, shalat hajad. Setelah berwudhu dan ziarah ke makam Sultan Malikussaleh, masyarakat dianjurkan untuk melaksanakan Shalat Hajat. Ritual ini menjadi inti dari proses bernazar. Karena disinilah menjadi proses interaksi antara manusia yang memiliki keinginan dengan sang pencipta yang bisa memenuhi keinginan manusia.

Dan keempat, proses konsultasi dengan pihak qadam. Pada proses ini masyarakat menyampaikkan tujuan dan keluhannya serta harapan yang diinginkan. Sehingga nantinya sang khadam mengetahui hal apa yang diinginkan peziarah. Setelah itu kemudian bisa diberi saran-saran dengan melalui penggunaan ie peunawa sesuai kebutuhan.

Tradisi bernazar dalam masyarakat Aceh dilakukan jika memiliki rasa sangat menginginkan sesuatu. Sehingga bentuk nazar yang dilakukan di makam Sutan Malikussaleh bervariasi berdasarkan tujuan dilakukannya nazar. Dilihat dari tujuan bernazar, di makam Sultan Malikussaleh masyarakat melakukan nazar ketika mempunyai keinginan untuk memiliki anak dari hubungan pernikahan yang sudah lama, keselamatan dan kesembuhan dari penyakit, dan keinginan untuk memperoleh kesuksesan.

Sebagai contoh, seorang ibu-ibu dalam kunjungannya menyampaikan perihal masalah yang dialami olehnya. Dengan pernikahan yang sudah memasuki usia sembilan tahun, akan tetapi belum juga dikaruniai seorang anak. Ia mengadu 
kepada teungku khadam akan keinginannya untuk memiliki keturunan. Atas dasar konsultasi tersebut, ibu tadi membuat suatu perjanjian yang berbentuk nazar.

Setelah keinginan yang harapkan menjadi kenyataan, nazar yang pernah diucapkan menjadi janji yang harus dipenuhi. Karena itu masyarakat memenuhi nazarnya sesuai dengan apa yang dinazarkan. Tahapan tersebut dilakukan dengan beberapa langkah, yaitu; kembali ziarah mengunjungi makam Sultan Malikussaleh, namun pada ziarah kali ini disertai dengan membawa segala kebutuhan yang diperlukan untuk memenuhi nazarnya. Kemudian setibanya di makam, peziarah menemui teungku khadam sebagai pembimbing pelepasan nazarnya.Sehingga akhirnya pelepasan nazar bisa dilakukan.

Seperti yang di lakukan oleh sekelompok masyarakat yang berkunjung ke makam Sultan Malikussaleh untuk melaksanakan turun tanah anak baru lahir. Hal itu dilakukan karena yang dinazarkan atau diharapkan telah terkabulkan sesuai dengan keinginannya.

\section{d. Belajar Sejarah}

Salah satu hikmah dan manfaat dari kegiatan ziarah kubur adalah sebagai salah satu cara mengenang jasa orang yang meninggal dunia dan meniru jejak langkah mereka. ${ }^{10}$ Seperti yang dilakukan oleh sekelompok pelajar dari salah satu Sekolah Menengah Pertama di Kota Lhokseumawe.

Keberadaan makam Sultan Malikussaleh sebagai cagar budaya dan situs sejarah menjadikan makam tersebut sebagai objek wisata ziarah untuk mengingat akan masa lalu masyarakat Aceh. Kemasyhuran kerajaan Samudera Pasee pada masa kegemilangannya meninggalkan kenangan sejarah yang sangat membekas. Keadaan ini menjadikan sejarah Sultan Malikussaleh penting untuk dipelajari. Tidak sedikit orang berziarah ke makam Sultan Malikussaleh untuk menggali atau mendengarkan sejarah. Baik oleh para arkeolog, sejarawan, masyarakat umum, mahasiswa. Selain itu sejarah keislaman Samudera Pasee bahkan dijadikan krikulum dalam pelajaran sekolah, sehingga peziarah yang memiliki tujuan yang sama juga terdapat dari kalangan para pelajar.

\footnotetext{
${ }^{10}$ Abdusshomad, Panduan Wisata Ziarah (Surabaya: Khalista, 2006 ) hal 25.
} 


\section{Ziarah Sebagai Identitas Sosial}

Agama senantiasa melekatkan makna dan penjelasan yang kuat sebagai justifikasi, legitimasi, sekaligus memberikan motivasi kenapa serangkaian praktekpraktek religius atau ritus dan peribadatan dilakukan (Budwanti, 2005). Mengenai kegiatan ziarah, setiap budaya dalam masyarakat yang beragama, memiliki cara tersendiri dalam berziarah. Hal ini sesuai dengan tuntunan yang dipegang oleh setiap pemeluk agama. Tentunya norma agama inilah yang menjadi dasar pembeda dalam membentuk perilaku manusia, termasuk dalam hal berziarah.

Perilaku ziarah memiliki korelasi terhadap identitas setiap pelaku ziarah. Perilaku setiap individu dilatarbelakangi oleh identitas yang mempengaruhi karakter dirinya dalam menghasilkan suatu tindakan (Afif, 2015). Sehingga

kegiatan ziarah yang dilakukan di Makam Sultan Malikussaleh tersebut menampilkan identitas sosial yang dibawa oleh setiap peziarah. Artinya, kelompok religius atau kesatuan identitas menjadi suatu dasar yang mempengaruhi perilaku dalam melakukan ritual ziarah.

Teori identitas sosial menjelaskan bahwa suatu kesatuan identitas dapat terlihat dari perilaku ataupun karakteristik. Hal ini di karenakan dalam sebuah identitas diri terdapat karakteristik yang dapat mejelaskan suatu perbedaan antara suatu individu dengan individu lainnya. Maka untuk mengidentifikasikan identitas para peziarah yang mengunjungi makam Sultan Malikussaleh, diurutkan berdasarkan kegiatan atau pun perilaku yang ditampilkan saat melakukan ziarah.

\section{a. Pola Ziarah Kelompok Identitas}

Identitas sosial terbentuk sebagai akibat dari keanggotaan seseorang dalam suatu kelompok kecil dari kebudayaannya. Secara umum tipe kelompok yang hadir sebagai peziarah di makam tersebut antara lain berdasarkan gender, pekerjaan, status dan profesi. Adanya stratifikasi sosial tersebut mempengaruhi tindakan atau perilaku masyarakat. Pola perilaku individu dalam kebudayaan masyarakat sebagai akibat dari adanya klasifikasi status sosial. Pada akhirnya dapat mempengaruhi gaya hidup (life style) masyarakat. Pada kasus ziarah makam Sultan Malikussaleh, identitas sosial masyarakat diperoleh dari hasil identifikasi terhadap 
perilaku ziarah yang ditampilkan berdasarkan persepsi serta harapan setiap pengunjung dalam berziarah.

1. Berdasarkan Gender

a. Suami/Ayah

Seorang suami sekaligus ayah tentunya memiliki harapan keluarganya akan selalu dalam keadaan sehat dan selamat. Dengan itu menjadikan alasan ketakutan bahwa akan adanya hal bahaya yang akan menimpa keluarganya, mendorong mereka melakukan upaya lebih dengan berdoa bahkan dengan bernazar. Nazar tersebut berdasarkan keinginan keselamatan istrinya saat melahirkan secara normal, serta kesehatan bagi anaknya. Dari itu ia bernazar akan melakukan ritual peutroen aneuk di makam Sultan Malikussaleh.

b. Istri/Ibu

Rasa yang dipenuhi dengan keinginan memiliki keturunan (anak) juga ikut serta memotivasi untuk melakukan ritual kegiatan ziarah. Ritual tersebut menjadikan ziarah sebagai perantara usaha dengan bernazar mendapatkan keturunan. Kemudian selain sebagai seorang istri, peran sebagai seorang ibu juga menjadikan dorongan untuk bernazar. Nazar ini dengan harapan agar terpenuhinya keinginan diberikan kesembuhan kepada sang anak yang telah lama sakit.

2. Berdasarkan Status

a. Santri (kelompok pengajian)

Seseorang yang ingin mendalami suatu hal dalam ilmu agama, yang tergabung dalam kelompok pengajian (seperti santri), terdorong untuk ingin mendapatkan kemudahan dalam menuntut ilmu. Selain itu, ada hal lebih yang ingin didapatkan oleh mereka yaitu keberkahan, ini menjadi pemicu bagi mereka untuk berdoa di makam, dengan menjadikan Sultan Malikussaleh sebagai wasilah doa. Bentuk dan cara doa yang dilakukan bermacam-macam. Ada sebagian yang hanya datang kemudian berdoa dengan membaca tahlil. Dan sebagian lagi dengan mengadakan kegiatan peuphoen kitab. Namun kedua cara tersebut menggunakan makam Sultan Malikussaleh sebagai media untuk mendapatkan keberkahan.

b. Pelajar dan Mahasiswa 
Kemasyhuran kerajaan Samudera Pasee pada masa kegemilangannya meninggalkan kenangan sejarah yang sangat membekas bagi masyarakat. Sehingga sejarah keislaman Samudera Pasee bahkan dijadikan krikulum dalam pelajaran sekolah. Hal ini menjadi motif atau alasan para pelajar ziarah ke makam Sultan Malikussaleh. Berbeda dengan pelajar, mahasiswa mengunjungi makam Sultan Malikussaleh berdasarkan agenda yang dibuat sendiri. Tujuannya untuk mendengarkan sejarah dengan secara langsung berhadapan dengan benda yang memiliki hubungan langsung dengan sosok Sultan Malikussaleh.

3. Berdasarkan Profesi/Pekerjaan

\section{a. Pegawai Negeri Sipil}

Berziarah atau berkunjung ke makam keramat merasa membawa pengaruh tertentu. Ketenangan suasana, ditambah dengan sejarah sang Sultan yang mengagumkan menjadi hal yang diinginkan seseorang untuk melepaskan kepenatan selama beraktivitas.

Kemudian kerumitan dan banyaknya permasalahan juga menjadi suatu alasan. Berdoa dengan tenang penuh dengan keinginan, berharap setelah kunjungan tersebut mendapatkan keberkahan melalui perantaraan kunjungan ke makam Sultan Malikussaleh. Sehingga efek yang diharapkan agar mendapatkan ketentraman, ketenangan, dan kelancaran dalam segala urusan.

b. Wiraswasta

Kegiatan ziarah sering kali dikaitkan dengan kehidupan dunia masyarakat. Ketentraman, kelancaran bahkan kesuksesan, dijadikan sebagai aspek dari akibat yang diinginkan dari ziarah. Seiring dengan kebutuhan spiritual dan banyaknya permasalahan yang dihadapi oleh individu dalam masyarakat kadangkala menjadikan rasionalitas mereka tidak berdaya sehingga timbul kecemasan dan ketakutan sehingga untuk mengatasinya adalah dengan berziarah yang diyakini dapat menenangkan jiwa.

c. Politisi

Selain untuk kepentingan sosial dan agama, kegitan ziarah makam juga dijadikan sebagai moment untuk kepentingan politik. Kegiatan ziarah yang dilakukan oleh golongan ini dilakukan dengan maksud deklarasi dan kampanye (Nurdin, 2016). Deklarasi tersebut dilakukan di makam Sultan Malikussaleh 
untuk mengambil keberkatan dan ukhuwah dari doa-doa para sultan untuk meraih kesuksesan dalam Pilkada.

\section{b. Pola Ziarah Masyarakat Aceh}

"Hukom ngon adat lagee zat ngoen sifeut,"merupakan filosofi hidup orang Aceh. Hadih majah (pepatah) ini menggambarkan integrasi antara hukum agama dan adat ${ }^{11}$ di Aceh bagaikan zat dengan sifat yang tidak dapat dipisahkan. Hal ini dapat dipahami bahwa antara budaya dan ajaran Islam telah berinteraksi dan berasimilasi secara harmonis dalam masyarakat Aceh (Nurdin, 2016). Dengan demikian budaya dan adat dalam masyarakat Aceh menyatu dengan agama. Islam menjadi patokan dalam adat dan budaya masyarakat Aceh. Artinya, Islam menjadi dasar rujukan dalam berperilaku atau berbudaya.

Agama menjadi bagian tradisi yang dilakukan turun-temurun. Sesuatu yang sudah diwariskan secara otomatis dikerjakan kembali atau dilanjutkan oleh generasi penerus (the continuous tradition) (Budiwanti, 2016). Keyakinan agama menjadi sumber inpirasi yang mempengaruhi pola pemikiran dan perilaku manusia terhadap sesama dan dunia (haryadi, 1995). Keterlibatan individu dalam suatu aktivitas keagamaan memiliki dampak pada penguatan dan penegasan terhadap identitasnya sebagai bagian dari kolektivitas kelompok yang lebih luas.

\section{c. Ciri-Ciri Identitas Ziarah Aceh}

Ziarah merupakan suatu fenomena budaya masyarakat. Suatu budaya tentunya berfungsi sebagai identitas dan citra suatu masyarakat. Faktor sejarah, kondisi dan posisi geografis, sistem sosial, politik dan ekonomi, serta perubahan nilai-nilai dalam masyarakat, menjadi komponen pembentuk identitas tersebut (Turner, 1994). Adapun ciri-ciri identitas ziarah Aceh ialah;

1) Pemahaman Islam yang dianut oleh mayoritas masyarakat Aceh ialah Ahalul Sunnah Wal Jama'ah dengan berpegang pada mazhab Syafi'i. Sehingga dalam berziarah, para peziarah di makam Sultan Malikussaleh

\footnotetext{
${ }^{11}$ Lihat Agus Budi Wibowo, Adat dan Islam di Aceh, hal 24, dikutip dari https://www.academia.edu/3526360/Adat_dan_Islam_di_Aceh_Customs_and_Islam_in_Aceh_?auto =download, Perkataan adat dalam bahasa Aceh berasal dari kata adah,yang dalam bahasa Arab berarti kebiasaan.
} 
melakukannya dengan cara yang dianjurkan dalam Islam sesuai dengan pemahaman tersebut, yaitu berzikir dan berdoa dengan menggunakan tawashul (Abdussomad, 2006).

2) Adanya ritual rah ulei di kuburan Sultan Malikussaleh. ${ }^{12}$ Kegiatan ini sering dijumpai dalam masyarakat adat Aceh saat melakukan ziarah. Ritual ini dilakukan untuk mengaharapkan keberkahan atau bertawashul dengan arwah ahli kubur tempat rah ulei dilakukan. Dalam keyakinan masyarakat yang melakukan ritual ini, doa ahli kubur akan diterima oleh Allah SWT, oleh karena itu dia meminta sesuatu melalui ahli kubur yang menurutnya keramat tersebut.

3) Makam Sultan Malikussaleh sebagai salah satu tempat pelaksanaan kegiatan peuphon kitab. Pada dasarnya kebiasaan ini dilakukan oleh hampir seluruh dayah atau pesantren tradisional di Aceh. ${ }^{13}$ Tradisi ini menjadi salah satu bukti penghormatan santri terhadap ilmu dan pemiliknya. Peuphoen kitab ini dilakukan dengan cara yang beragam. Ada yang melakukannya di dayah masing-masing, ada juga yang melakukannya dengan mengunjungi dayah-dayah tertentu yang terkenal berjasa melahirkan kader-kader ulama. Bahkan sebagian masyarakat mengambil waktu untuk berkunjung ke tempat ulama yang telah tiada, seperti ke makam Sultan Malikussaleh.

4) Peusijuk merupakan salah satu tradisi yang juga sebagai bagian dari adat masyarakat Aceh. Peusijuk dilakukan dengan tujuan untuk untuk memohon keselamatan, ketentraman, kebahagiaan dan juga keberkahan dalam hidup (Rizal, 2014). Ritual peusijuk di makam Sultan Malikussaleh, dilakukan setelah dilaksanakannya peuphoen kitab, dengan itu fungsi peusijuk disini bagi yang melakukannya ialah mengaharap keberkahan serta kelancaran dalam menuntut ilmu.

12 Kegiatan ini merupakan suatu ritual membasuh muka dengan air yang dilakukan di bagian kepala kuburan. Biasanya kegiatan rah ule ini dilakukan dengan menggunakan air yang dicampur dengan beberapa jenis bunga dan jeruk purut. Namun di makam Sultan Malikussaleh, peziarah mencuci muka (rah ule) hanya dengan air biasa. Walaupun demikian hal ini tentunya tidak menjadi suatu bentuk kekurangan.

${ }^{13} \mathrm{Nu}$ Online, Tradisi Peuphon Kitab di Dayah Jam'iyah Al-Aziziyah, dikutip dari https://www.nu.or.id/post/read/56608/tradisi-peuphon-kitab-di-dayah-jamrsquoiyah-alaziziyah, Jumat 26 September 2014. 
5) Sebagian masyarakat menjadikan makam sebagai media dalam bernazar. Hal ini seperti halnya masyarakat berziarah ke makam Sultan Malikussaleh dengan tujuan bernazar atau melepaskan nazarnya. Nazar tersebut dilakukan karena ada sesatu keinginan atau harapan yang ingin dicapai. Akan tetapi dalam hal ini melalui perantaraan (washilah) kesalihan Sultan Malikussaleh. Menariknya, selain bernazar membaca surat Al-Quran, bersedekah dan menyembelih kambing, nazar masyarakat yang berziarah ke makam Sultan Malikussaleh juga tidak jauh dari pada ritual atau tradisi masyarakat Aceh. Misalnya seperti ritual peutroen aneuk (turun tanah bayi).

Membahas tentang wisata ziarah di makam Sultan Malikussaleh sebagai identitas sosial masyarakat, nilai keacehan dilihat dari segi perilaku masyarakat Aceh yang tertuang dalam pemahaman dan sikap beragama, adat istiadat, hukum, ahklak, kesenian, cara beristiadat dan sebagainya (Ali, 2018). Karakter sinkretik dari perilaku beragama masyarakat Aceh yang menggabungkan Islam dengan kepercayaan lokal tercermin dari pembacaan doa dan keterlibatan roh leluhur sebagai pembawa berkah. Artinya, perilaku masyarakat di makam Sultan Malikussaleh menjadi gambaran karakter masyarakat Aceh.

Dari beberapa uraian kegiatan yang dilakukan di Makam Sultan Malikussaleh di atas, menunjukkan perwakilan perilaku masyarakat Aceh mengenai pemahaman agama dan adat istiadat. Dengan demikian perilaku-perilaku yang muncul dari kegiatan ziarah tersebut menunjukkan identitas sosial masyarakat Aceh.

\section{Kesimpulan}

Kegiatan ziarah di makam Sultan Malikussaleh dilakukan sebagaimana umumnya masyarakat Aceh berziarah. Akan tetapi ada beberapa kegiatan yang menunjuk pada arah etnisitas Aceh, yaitu tradisi Aceh yang dilakukan di makam Sultan Malikussaleh. Diantaranya ialah berdoa dengan tawashul, mengambil batu dari kubur sebagai objek penawar penyakit, peuphon kitab, bernazar, dan peutroen aneuk (turun tanah bayi). Dari kesemua perilaku tersebut merupakan cara pandang agama dan adat masyarakat yang menjadi identitas keacehan. 


\section{Daftar Pustaka}

Abdusshomad. 2006. Panduan Wisata Ziarah. Surabaya: Khalista.

Afif, Afthonul. 2015. Teori Identitas Sosial. Yogyakarta: UII Press.

Agus Budi Wibowo, Adat dan Islam di Aceh, hal 24, dikutip dari https://www.academia.edu/3526360/Adat_dan_Islam_di_Aceh_Customs_a nd_Islam_in_Aceh_?auto=download.

Agus Salim Chamidi. 2017. 'Membedah Identitas Santri': Jurnal An-Nadhah. Vol.11. 1 Januari 2017.

Ali. 2018. Identitas Aceh Dalam Perspektif Syariat dan Adat. 2013, hal 15-18, dikutip dari Nana Noviana, Integritas Kearifan Lokal Budaya Masyarakat Aceh dalam tradisi Peusijuk: Jurnal DESKOVI, Vol 1, No 1, Desember 2018, hal 30 .

Aniek Rahmaniah. 2012. Budaya dan Identitas. Sidoarjo: PT Dwiputra Pustaka jaya.

Biroli, Alfan "Rasionalitas wisatawan wisata pilgrim”: Jurnal Analisa Sosiologi, vol 4. No 2 .

Budwanti, Erni. 2005. "Islam dalam Konteks Budaya Lokal (Studi Kasus DI Bayan, Lombok Barat); Jurnal Masyarakat Indonesia, Vol 31, NO. 2, 2005.

Hariyadi, M dkk. 1995. Islam di Indonesia. Jakarta:Yayasan Festival Istiqlal.

Hariyadi, M. dkk, 1995. Islam di Indonesia. Jakarta:Yayasan Festival Istiqlal.

Heriyanto, Arief. Kelas Sosial, Status Sosial, Peranan Sosial dan Pengaruhnya, Modul Belajar, No. Sos.II.04. hal 17.

https://www.kompasiana.com, Peusijuk, Tradisi warisan Leluhur Masyarakat Aceh.7 Juni 2013).

Ihromi, 2006. Pokok-Pokok Antropologi Budaya. Jakarta.

Lihat Agus Budi Wibowo, Adat dan Islam di Aceh, hal 24, dikutip dari https://www.academia.edu/3526360/Adat_dan_Islam_di_Aceh_Customs_a nd_Islam_in_Aceh_?auto=download. Perkataan adat dalam bahasa Aceh berasal dari kata adah,yang dalam bahasa Arab berarti kebiasaan.

Moleong, Lexy J, 2014. Metodelogi Penelitian Kualitatif. Bandung: PT Remaja Rosdakarya.

Ndraha, Talizuduhu. 2005. Teori Budaya Organisasi. Jakarta : PT Rineka Cipta. 
Noviana, Nana. 2018. "Integritas Kearifan Lokal Budaya Masyarakat Aceh dalam tradisi Peusijuk". Jurnal DESKOVI, Vol 1, No 1, Desember 2018.

$\mathrm{Nu}$ Online, Tradisi Peuphon Kitab di Dayah Jam'iyah Al-Aziziyah, dikutip dari https://www.nu.or.id/post/read/56608/tradisi-peuphon-kitab-di-dayahjamrsquoiyah-al-aziziyah, Jumat 26 September 2014.

Nurdin, Abidin. 2016. "Integrasi Agama dan Budaya (Kajian Tentang Tradisi Maulod dalam Masyarakat Aceh)": Jurnal el Harakah, Vol.18 No 1 Tahun 2016.

Rahmaniah, Aniek. 2012.Budaya dan Identitas. Sidoarjo: PT Dwiputra Pustaka jaya.

Rizal, Chairoel, dkk. 2018. Konstruksi Makna Tradisi Peusijuk dalam Budaya Aceh: Jurnal Antropologi, Isu-Isu Sosial Budaya, Vol 20, No 2, Desember 2018.

Saifullah Nurdin, Ayah Panton Deklarasi di Makam Sultan Malikussaleh, di kutip dari https://m.rri.co.id/lhokseumawe/post/berita/297840/pilkadaserentak/ayah-panton-deklarasi-di-makam-sultan-malikussaleh.html, 9 Agustus 2016.

Turner, Charles Hampden. 1994. dalam Talizuduhu Ndraha, Teori Budaya Organisasi. Jakarta : PT Rineka Cipta, 2005. 